\title{
The Influence Of Marketing Communications On Loyalty Through Satisfaction
}

\begin{abstract}
Ahmad Fadli ${ }^{*}$
Fiqrida Amalia ${ }^{2}$

Emma Novirsari ${ }^{3}$

Ratih Amelia ${ }^{4}$

Muhammad Fathoni ${ }^{5}$

1,2,3Management Program, Universitas Mahkota Tricom Unggul, Batam, Indonesia

4,5Politeknik Unggul LP3M, Medan, Indonesia

ARTICLE INFO ABSTRACT

ISSN: 2723-1097

The main objective of this study is to determine the role of satisfaction in mediating marketing communications on visitor loyalty in Lake Toba. The target population and sample in this study were the visitors to Lake Toba who were

Keywords: selected by accidental sampling as many as 125 people. Path analysis in this study was chosen to see the direct and indirect role of satisfaction in mediating

Marketing

Communication,

Satisfaction, Loyalty marketing communications on loyalty. The results of study 1) direct marketing communication has a positive and significant effect on visitor satisfaction at Lake Toba, 2) directly marketing communication does not affect visitor loyalty in Lake Toba. 3) Satisfaction directly has a positive and significant effect on visitor satisfaction at Lake Toba. 4) indirectly, satisfaction has a role in mediating marketing communication on visitor loyalty in Lake Toba.
\end{abstract}

\section{Introduction}

The development of the tourism business today has received a lot of attention, especially from the government. Where it is hoped that increasing the tourism sector will be able to continue to improve the community's economy (Saragih, 2020). So that good management is needed in managing the tourism sector in increasing visitor

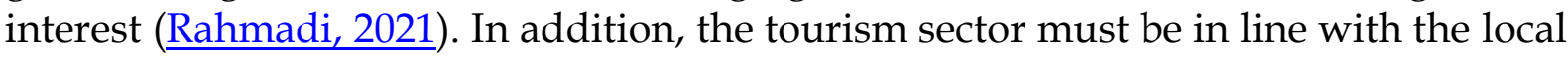
wisdom that exists in each region (Dewi, 2020). Thus it will be a unique feature that can be offered by each region to increase the interest of visitors (Hidayatullah, Windhyastiti, Patalo, \& Rachmawati, 2020).

Lake Toba is one of the leading tourist destinations, especially in the province of North Sumatra. The discourse to make Lake Toba one of the world's destinations launched by the central government is an effort to make Lake Toba aligned with the island of Bali (Azhar, 2020). To realize this discourse, of course, is a very difficult job and cooperation is needed by all parties (Kencana, 2019). Launching from Bisnis.com the number of foreign tourists visiting North Sumatra through 4 entrances, grew 10.17 percent annually in 2019. Based on data released by the Central Statistics

Journal of Business and Management Review Vol. 2 No. 122021 Page 850-860

DOI: 10.47153/jbmr212.2982021

*Corresponding Author

Email address: novir.emma@gmail.com 
Agency (BPS) of North Sumatra Province (Sumut), the number of foreign tourists visiting North Sumatra in December 2019 reached 24,113 visits. The realization rose 7.94 percent compared to the number of foreign tourists who came in November 2019 reaching 22,340 visits. In addition, in 2019, the COVID-19 outbreak has hit the world. of course, this will make the number of tourists will be smaller to travel to Lake Toba. The Lake Toba authority can only maximize domestic tourists so that the economy in Lake Toba is still alive. So that an effective marketing communication strategy is needed to increase the interest of visitors to come and vacation to Lake Toba.

A visitor's loyalty to a tourist attraction certainly has an important meaning for both the local government and the central government (Nasution, 2020). Loyal visitors tend to recommend to their closest colleagues in providing references for tourist destinations (Nabila, 2020). Then not only to recommend to others, but a loyal visitor will also visit again in the future (Listyawati, 2019). This means that visitor loyalty will not be separated from the best experience. So that visitors feel confident about the beauty and uniqueness of the tourist attraction (Achsa, 2021).

Loyal visitors will generally buy the brand even though they are faced with many alternative brands of competing products that offer superior product characteristics from various angles (Durianto, 2013). Customer loyalty is a customer's commitment to a brand, store, or supplier based on a very positive nature in longterm purchases (Tjiptono, 2012). The loyalty of a customer will be seen from the frequency of repeat purchases. High or low customer loyalty can be distinguished into no loyalty, weak loyalty, hidden loyalty, and premium loyalty (Griffin, 2010).

Customer satisfaction is a very important factor for the company. This is because the sense of customer satisfaction is a reflection of the company's success (Tjiptono, 2011). The sense of satisfaction should be measured already how far the sense of satisfaction felt by customers. One way is to evaluate the level of complaints (Keller, 2016). The purpose of measuring satisfaction can help the company become a source of company income (Tjiptono, 2014). The satisfaction of a customer cannot be separated from the company's ability to respond and provide good empathy for the problems felt (Nasib, 2017). Companies need to continue to open themselves to receive criticism and suggestions in improving the value of expectations from their customers (Nasib, 2019). In addition, efforts to measure customer satisfaction must also be carried out on an ongoing basis (Nafil \& Nasib 2019). The goal is to create a competitive advantage for the company against its competitors (S. Nasib, 2021). The results of the study prove that the company's ability to create a sense of satisfaction for its customers tends to increase loyalty (Ningsih, 2020; Martin, 2021).

Marketing communication is a company's effort to provide information to persuade customers to the product or service of a brand. In addition, marketing communication also tries to remind customers of the company's products or services 
(Keller, 2016). There are at least nine elements that exist in marketing communications. The nine elements consist of communicators, messages, sending functions, channels, receiving functions, communicants, responses, feedback, and interference (Kertajaya, 2008). Furthermore, in providing information to customers, the company carries out marketing communication activities through advertising in the mass media, direct marketing, sales promotion, personal selling, interactive marketing, and building public relations (Morissan, 2012).

Marketing communications carried out so far, both district and provincial governments have not maximally introduced Lake Toba to the wider community. One example that has been done so far is the annual party. For example, the anniversary of Lake Toba and bicycle tours. Even though efforts to introduce Lake Toba are still many ways that can be done. So often visitors who come to Lake Toba do not get entertainment other than its natural beauty. Of course, this makes visitors' expectations of natural beauty not matched by events or entertainment. Marketing communication is also considered important in increasing consumer satisfaction in using products or services (Ismail, 2018). This sense of satisfaction in consumers will have an impact on customer loyalty (Azizah, 2019). This shows that the satisfaction of a consumer has a role in mediating between marketing communication and customer loyalty (Baharuddin, 2020).

\section{Literature Review}

\section{Loyalty}

Consumer loyalty is a deeply held commitment to buy or re-support a preferred product or service in the future despite situational influences and marketing efforts having the potential to cause customers to switch (Keller, 2016). The loyalty of a visitor can be seen from a sense of loyalty to visit tourist objects in the future (Azhar, 2020). The beauty of the natural panorama makes visitors interested in making visits in the future (Lesmana \& Nabila, 2020). Loyal visitors will certainly recommend their closest friends to test these attractions (Hidayatullah et all, 2020). The results of research conducted by Listyawati, (2019); Hanny, (2021) stated that marketing communication and consumer satisfaction have a positive and significant influence on customer loyalty. This means that when the company can maximize communication and satisfaction, it will have an impact on increasing customer loyalty.

H1: Marketing communication affects visitor loyalty through Lake Toba visitor satisfaction

\section{Satisfaction}


Customer satisfaction is a very important factor for the company. This is because the sense of customer satisfaction is a reflection of the company's success (Tjiptono, 2011). The sense of satisfaction should be measured already the extent of the sense of satisfaction felt by customers. One way is to evaluate the level of complaints (Keller, 2016). The purpose of measuring satisfaction can help the company become a source of company income (Tjiptono, 2014). A sense of satisfaction in visiting tourist destinations will be seen as important, especially for managers (Nabila, 2020). One of them is by using the disconfirmation paradigm which states that tourists have previous expectations that they compare with the perceived results of a service (Kholiq, 2020). Measuring satisfaction with three items, the first relates to whether or not tourists are happy with their decision to visit a tourism destination, the second is the belief that choosing a related destination is the right thing and third is the overall level of satisfaction during a trip to a tourism destination (Nasib et all 2021).

The results of previous research conducted by Ningsih, (2020); Martin, (2021); Daulay, (2021) stated that satisfaction had a significant effect on customer loyalty. A customer's satisfaction is obtained when the company is able to understand the value of the expectations that exist within the customer.

H2: Satisfaction affects the loyalty of visitors to Lake Toba

\section{Marketing Communication}

Marketing communication is a company's effort in providing information to persuade customers to the product or service of a brand. In addition, marketing communication also tries to remind customers of the company's products or services (Keller, 2016). There are at least nine elements that exist in marketing communications. The nine elements consist of communicators, messages, sending functions, channels, receiving functions, communicants, responses, feedback, and disturbances (Kertajaya, 2008). Furthermore, in providing information to customers, the company carries out marketing communication activities through advertising in the mass media, direct marketing, sales promotion, personal selling, interactive marketing, and building public relations (Morissan, 2012).

The results of previous research conducted by Nafil, (2019); Patalo, (2020) which states that marketing communication has an effect on customer satisfaction and loyalty

H3: Marketing communication affects visitor satisfaction of Lake Toba

H4: Marketing communication affects the loyalty of visitors to Lake Toba 
Previous research that is appropriate or close to the same as this research consists of research conducted by Kilango, (2017). Because of the consequences, the conclusions and discussion of the study are also based on the analysis. Research conducted by Agyei, (2020). Based on these findings, this study recommends that banks continue to strive to achieve customer satisfaction by meeting customer needs and desires because it can lead to customer loyalty. This can be done by understanding all the factors that affect customer satisfaction. Also, it is recommended that public relations should not be discarded but strengthened to complement other marketing communications mixes to help drive customer loyalty in the Ghanaian banking industry.

Research conducted by Sadq, (2021), this study will be of interest to the Umrah travel industry, Malaysia, and all other countries, in understanding how marketing mix strategy is essential in maintaining long-term relationships with customers. Research conducted by Rahman, (2021) states that integrated marketing communication has an indirect and significant effect on loyalty through satisfaction, this shows the higher the integrated marketing communication implemented by the hotel will create hotel guest loyalty through satisfaction.

Research conducted by Tham, (2019) stated that customer satisfaction has a positive effect on customer loyalty. The findings also show that product, promotion, place, and price have a positive effect on customer loyalty through the satisfaction of SME customers for food and beverage products in Malaysia. Research conducted by Hanny, (2021) states that the test results show that partially marketing communication has a significant effect on loyalty, satisfaction, and advertising has no significant effect on loyalty. Simultaneously marketing communication, satisfaction and advertising have a significant effect on consumer loyalty. The theoretical framework of the research is as follows:

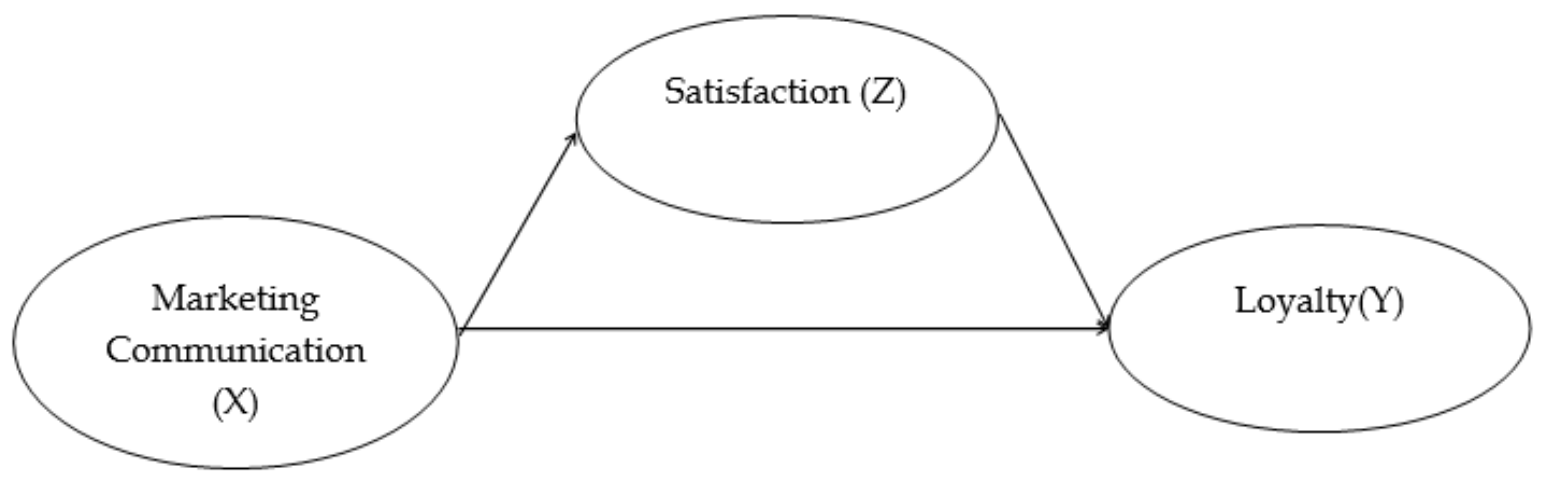

Figure 1. Theoretical Thinking Framework

Method 
The research approach in this research is path analysis research with data analysis using path analysis. Path analysis is also used to determine the direct and indirect effects of the variables that test and determine how much influence marketing communication has on satisfaction and its impact on loyalty. Furthermore, the population in this study are regular visitors who come to Lake Toba where it is estimated that every month there are 125 visitors. While the sampling technique used accidental sampling. These 125 visitors were selected when researchers met directly at the location of Lake Toba.

\section{Result and Discussion}

\section{Effect of Marketing Communication on Satisfaction}

It is known that the $\mathrm{t}$ arithmetic value of marketing communication is $4.685>\mathrm{t}$ table 1.979 and the significance value $(0.000)$ is smaller than alpha $5 \%(0.05)$. Based on the results obtained, reject $\mathrm{H} 0$ and accept. Ha for the marketing communication variable. Thus partially the marketing communication variable has a positive and significant effect on visitor satisfaction of Lake Toba. The results of this study support the results of previous studies Mu'afiah, (2020); Agyei, (2020) having a positive and significant effect on customer satisfaction. Marketing communications must pay attention to aspects of truth and information received by customers. Companies must pay attention to bombastic marketing communications but are not proven than promised, then this will trigger complaints from customers (Nasib, 2019). The findings in this study imply that in promoting Lake Toba to the wider community, involving officials from the president, ministers, and traditional Batak shops is very effective. The visitors feel confident that Lake Toba will be better and more wellmaintained than before.

\section{Effect of Marketing Communication on Loyalty}

It is known that the $\mathrm{t}$ arithmetic value of marketing communication is $1.898<\mathrm{t}$ table 1.979 and the significance value (0.060) is greater than alpha 5\% (0.05). Based on the results obtained, then reject $\mathrm{Ha}$ and accept. $\mathrm{HO}$ for the marketing communication variable. Thus, partially the marketing communication variable has no effect on the loyalty of visitors to Lake Toba. The results of this study are in line with the results of research conducted by Nafil, (2019); Patalo, (2020); Siswanto, (2020) which states that marketing communication has a positive and significant effect on customer loyalty. The implication of the findings in this study shows that the use of social media which has been assessed so far has not been able to increase the loyalty of Lake Toba visitors. This is because as a visitor, you will not immediately believe the information on social media if you have not directly proven what you see.

\section{The Effect of Satisfaction on Loyalty}


It is known that the $\mathrm{t}$-count for satisfaction is $13,221>$ ttable 1.979 and the significance value (0.000) is smaller than alpha $5 \%(0.05)$. Based on the results obtained, reject $\mathrm{HO}$ and accept. Ha for the satisfaction variable. Thus partially the satisfaction variable has a positive and significant effect on visitor loyalty to Lake Toba. The results of this study support the previous research conducted by Akbar, (2020); Martin, (2021); Daulay, (2021) which states that visitor satisfaction has a positive and significant effect on visitor loyalty. The implication in this study is that visitors to Lake Toba will feel satisfied when what they perceive is what they receive. To get feedback from existing visitors, the Lake Toba Authority Implementing Body must continue to conduct visitor satisfaction surveys on an ongoing basis. The survey results will be used as material for improvement.

\section{Effect of Marketing Communication on Loyalty through Satisfaction}

The direct effect of marketing communication on loyalty is by looking at the regression coefficient $\mathrm{P} 4$ of 0.108 . The indirect effect of marketing communication on loyalty through satisfaction is seen from the multiplication of the marketing communication regression coefficient on satisfaction with the regression coefficient value of satisfaction on loyalty, namely $\mathrm{P} 2 \times \mathrm{P} 5=0.353 \times 0.834=0.294$. So it can be concluded that the coefficient of indirect influence is $\mathrm{P} 2 \times \mathrm{P} 5>\mathrm{P} 4(0.294>0.108)$. This means that satisfaction plays a role in mediating marketing communications on the loyalty of visitors to Lake Toba. The results of this study support the results of previous research conducted by Listyawati, (2019); Ningsih, (2020); Nasib et all (2021) which states that marketing communication has a positive effect on loyalty through visitor satisfaction. The implications of the findings in this study indicate that the use of social media as marketing communication is quite effective in increasing visitor satisfaction. Where visitors feel they can easily find various sources of information about the concept of tourist destinations on Lake Toba. Visitors who are satisfied will have the right tourist references that will be used as holiday materials in the future.

\section{Conclusion}

Based on the results of the research and discussion above, it can be concluded that marketing communication directly has a positive and significant effect on visitor satisfaction and loyalty at Lake Toba. Indirectly, marketing communication has a positive effect on visitor loyalty through visitor satisfaction at Lake Toba. This shows that the satisfaction of a visitor has an important role in mediating marketing communications on visitor loyalty in Lake Toba.

The following are the study's recommendations: 
1. The usage of social media should be controlled by certain sections that are in charge of the content that will be distributed to the general public. So that the material submitted is accurate, and to keep an eye on fake news about Lake Toba.

2. It is recommended that amenities such as prayer rooms, restrooms, and parking lots be improved and well-managed. According to the father figure who later became an Indonesian minister, this can be accomplished through involving startup enterprises.

\section{Acknowledgment}

The author expresses appreciation to members who have contributed a lot in terms of funds, energy, and thoughts. So that this research was completed on a predetermined schedule. Finally, the author gives his respects to the Director-General of Higher Education who has given his trust through the novice lecturer research funding scheme

\section{References}

Achsa, I. N. B. R. A. (2021). Anteseden Loyalitas Tamu Pada Homestay Di Kawasan Balai Ekonomi Desa (Balkondes) Borobudur. Jurnal Perilaku Dan Strategi Bisnis, 9(1), 1-15.

Agyei, I. O.-B. S. D. (2020). Effect Of Customer Satisfaction And Marketing Communication Mix On Customers' Loyalty In The Ghanaian Banking Industry. European Journal of Management and Marketing Studies, 5(4), 22-40. https:// doi.org/10.46827/ejmms.v5i4.891

Akbar, P. I. P. D. (2020). Pengaruh Telemarketing dalam Kegiatan Business Matching dalam Pameran Indonesia Maritime Expo 2019. JBEvent, 1(2), 31-36.

Apriliyanti, Ester; Hudayah, Syarifah; Zainurossalamia, Saida. (2020). P Tourist Satisfaction Of Commercial Images As A Center Of Cultural Reflection Typical Of Samarinda City. JUrnal Manajemen, 12(1), 145-153.

Azhar, M. R. M. D. K. G. J. M. E. (2020). Model Elektronik Word of Mouth: Citra Destinasi, Kepuasan dan Loyalitas Wisatawan. Jurnal Ilmiah Manajemen Dan Bisnis, 21(April), 1-19.

Azizah, N. T. (2019). Pengaruh Komunikasi Pelayanan Dan Kepuasan Terhadap Loyalitas Pelanggan Pada PT. Cendana Tour \& Travel Banda Aceh. Jurnal Ilmiah Manajemen Muhammadiyah Aceh (JIMMA), 9(2), 1-20.

Baharuddin, S. J. K. S. N. D. (2020). Pengaruh Relationship Marketing Terhadap Loyalitas pelanggan dan Customer Satisfaction sebagai variabel Intervening Pada Kilinik Kecantikan Ressty Aesthetic Clinic di Kota Makassar. Jurnal Sosio Sains, 6(1), 11-26.

Daulay, N. S. Z. R. (2021). Memaksimumkan Brand Loyalty , Brand Trust Dan Brand Image Melalui Satisfaction. Ekuivalensi, 7(1), 38-47.

Dewi, A. R. I. W. S. N. (2020). Pengaruh Brand Image Terhadap Loyalitas Wisatawan 
Berbelanja Di Toko Oleh-Oleh Rama Krisna Tuban. Jurnal IPTA, 8(1), 83-93. https:/ / doi.org/10.24843/ipta.2020.v08.i01.p11

Durianto, D. (2013). Strategi Menaklukan Pasar Melalui Riset Ekuitas dan Perilaku Merek Edisi 10. Jakarta: PT Gramedia Pustaka Utama.

Griffin, J. (2010). Customer Loyalty, Menumbuhkan dan Mempertahankan Kesetiaan Pelanggan. Alih Bahasa Dwi Kartini Yahya. Jakarta: Erlangga.

Hanny, I. W. hammad A. A. C. C. B. P. J. P. (2021). Effect of Marketing Communication, Satisfaction and Advertising on Consumer Loyalty in PT . Prudential Life Insurance. Journal of Research in Business, Economics, and Education, 3(3), 1-6.

Nafil, Herwan; Nasib (2019). Optimalisasi Kepuasan Pelayanan Dan Komunikasi Pada Supermarket Mr. Ben Medan. Juranl Ekonomi Dan Kebijakan Publik, 4(2), 111-118.

Hidayatullah, S., Windhyastiti, I., Patalo, R. G., \& Rachmawati, I. K. (2020). Citra Destinasi: Pengaruhnya terhadap Kepuasan dan Loyalitas Wisatawan yang Berkunjung ke Gunung Bromo. Jurnal Manajemen Dan Kewirausahaan, 8(1), 96108. https:/ / doi.org/10.26905/jmdk.v8i1.4246

Nasib; Panggabean, Helena Louise; Khairani, Rafida; Daulay, Zulia Rifda; HS, Widy Hastuty (2021). Increasing Brand Trust through Marketing Communication and Its Impact on School principal's Loyalty. Budapest International Research and Critics Institute (BIRCI-Journal): Humanities and Social Sciences, 4(2), 2208-2216. https://doi.org/10.33258/ birci.v4i2.1913

Ismail, A. S. A. M. A. M. (2018). The Influence of Customers Involvement and Brand Trust on Decisions of Purchase of Products Through Intention to Buy as Intervienning Variable (Study on Eiwa Instagram Account). Hasanuddin Journal of Applied Business and Entrepreneurship, 1(3), 37-50.

Keller, P. K. K. L. (2016). Manajemen Pemasaran Edisi 12. Jakarta: Erlangga.

Kencana, I. V. O. S. W. H. (2019). Pengaruh Terpaan Film Toba Dreams Dan Brand Image Sountrack Film Aut Boi Nian Terhadap Minat Atraksi Wisata Danau Toba. Jurnal IKRA-ITH Humaniora, 3(3), 117-130.

Kertajaya, Hermawan. (2008). Seri 9 Elemen Marketing Hermawan Kartajaya on Marketing Mix. Bandung: Mizan Pustaka.

Kholiq, K. A. P. A. (2020). Pengaruh Kualitas Pelayanan Dan Pengemasan Daya Tarik Wisata Terhadap Kepuasan Wisatawan Di Ngebel Ponorogo. Sosiologi Reflektif, 14(2), 407-423.

Kilango, R. A. S. S. X. N. C. (2017). Marketing Communication Based on Customer Satisfaction and Loyalty: Zantel Tanzania. International Journal of Innovation,

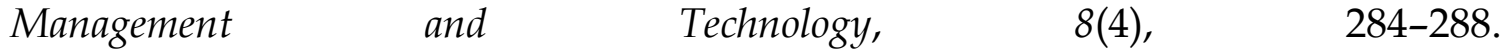
https:/ / doi.org/10.18178/ijimt.2017.8.4.742

Lesmana, R., \& Nabila, N. I. (2020). Analisis Loyalitas Wisatawan Lokal Melalui Kepuasan Wisatawan Studi Kasus Pada Objek Wisata Kepulauan Seribu Jakarta. PROCEEDINGS UNIVERSITAS PAMULANG, 1(1). 
Listyawati, I. H. (2019). Pengaruh Fasilitas Wisata, Citra Destinasi, dan Kepusan Terhadap Loyalitas Wisatawan. Jurnal Manajemen Administrasi, VI(2), 35-44. Retrieved from http://jurnal.amaypk.ac.id/index.php/jbma/article/view/78

Martin, I. L. N. R. K. C. H. (2021). The Role of Costumer Satisfaction in Mediating the Relationship Between Service Quality and Price on Costumer Loyalty. Enrichment: Journal of Management, 12(1), 400-411.

Morissan. (2012). Periklanan Komunikasi Pemasaran Terpadu. Jakarta: Kencana Prenada Media Group.

Mu'afiah, N. (2020). Pengaruh Marketing Communication Terhadap Customer Satisfaction Pada Perusahaan Jasa PT. Aaji Manulife Surabaya. Jurnal Mitra Manajemen, 4(11), 1558-1572. Retrieved from http://ejurnalmitramanajemen.com/index.php/jmm/article/view/125/69

Nabila, Osa L. W. H. N. I. (2020). Analisis Loyalitas Wisatawan Lokal Melalui Kepuasan Wisatawan Studi Kasus Pada Objek Wisata Kepulauan Seribu Jakarta. JIMF (Jurnal Ilmiah Manajemen Forkamma), 3(1), 142-149. Retrieved from http://openjournal.unpam.ac.id/index.php/Proceedings/article/view/5198

Nabila, R. L. N. I. (2020). Analisis Loyalitas Wisatawan Lokal Melalui Kepuasan Wisatawan Studi Kasus Pada Objek Wisata Kepulauan Seribu Jakarta. In Enhancing Innovations for Sustainable Development: Dissemination of Unpam's Research Result (pp. 1-14).

Nasib. (2017). Pengaruh Kualitas Pelayanan Terhadap Kepuasan Pelanggan (Studi Kasus Pada Kola Renan Bengawan Solo Pangkalan Brandan). Jurnal Ilmiah Manajemen E Bisnis, 18(1), 30-44.

Nasib, A. F. (2019). Konsep Intisari Strategi pemasaran. Jawa Tengah: CV. Pena Persada. Nasib, M. S. (2019). Pengukuran Kepuasan Pengguna Kereta Api Indonesia (Persero) Medan Melalui Fasilitas Dan Pelayanan. Abdi Ilmu, 12(2), 51-57.

Nasib, S. (2021). Maksimalisasi Peningkatan Kepuasan Pelanggan Pada PT. Lautan Abadi Pratama Melalui Promosi Dan Kualitas Pelayanan Pada PT. Lautan Abadi Pratama. Ekonomi Bisnis, 27(1), 550-561.

Nasution, S. K. A. M. U. C. (2020). Pengaruh Brand Image dan Sales Promotion Terhadap Keputusan Pembelian menggunakan Aplikasi OVO Di Royal Plaza Surabaya. Jurnal Dinamika Adninistrasi Bisnis, 6(1), 1-10. Retrieved from http://library1.nida.ac.th/termpaper6/sd/2554/19755.pdf

Ningsih, N. I. L. K. N. C. H. A. W. (2020). Online Shopping the Satisfaction through Perceived Quality and It 's Impact On Customer Loyalty. International Journal of Business and Management Invention (IJBMI), 9(3), 56-61.

Patalo, S. H. I. K. R. E. A. A. W. R. G. (2020). Peran Sistem Informasi Pemasaran, Kualitas Pelayanan dan Entrepreneurial marketing serta Kepuasan Terhadap Loyalitas Generasi Milenial Berkunjung ke Tempat Wisata. Jurnal Ilmiah Bisnis Dan Ekonomi Asia, 14(1), 35-45. https://doi.org/10.32812/jibeka.v14i1.148

Rahmadi, B. A. (2021). Pengaruh Citra, Kualitas dan Kepuasan Terhadap Loyalitas Wisatawan Wisata Bahari Pulau Derawan. Change Agent For Management Journal 
(CAM), 5(1), 52-63.

Rahman, F. J. K. R. Z. (2021). The Effect of Integrated Marketing Communication on Image, Satisfaction and Loyalty of Hotel Guests in Makassar City. International Journal of Health, Economics, and Social Sciences (IJHESS), 3(2), 74-91.

Sadq, B. A. O. A. H. N. M. D. A. Z. M. (2021). The effects on customer satisfaction and customer loyalty by integrating marketing communication and after sale service into the traditional marketing mix model of Umrah travel services in Malaysia. Journal of Islamic Marketing, 12(2), 363-388. https://doi.org/10.1108/JIMA-092019-0198

Saragih, H. M. P. S. R. S. (2020). Brand image sebagai Strategi Peningkatan Jumlah Wisatawan Danau Toba "Monaco of Asia" di Kabupaten Samosir. Journal of Education, Humaniora and Social Sciences (JEHSS), 3(2), 533-537. https://doi.org/10.34007/jehss.v3i2.357

Siswanto, T. S. R. M. R. H. P. (2020). Pengaruh Tangible, Responsiveness, Trust, Communication, Dan Satisfaction Terhadap Loyalitas (Investigasi: Bank "Dana***" Di Mall "Tsr"). Jurnal Ilmu Manajemen Terapan, 1(5), 522-533. https:/ / doi.org/10.31933/jimt.v1i5.224

Tham, S. A. S. A. K. T. A. K. J. (2019). Measuring The Critical Effect Of Marketing Mix On Customer Loyalty Through Customer Satisfaction In Food And Beverage Products. Management Science Letters, 9(9), 1385-1396. https:/ / doi.org/10.5267/j.msl.2019.5.012

Tjiptono, F. (2012). Strategi Pemasaran Edisi 3. Yogyakarta: Andi.

Tjiptono, F. (2014). Pemasan Jasa - Prinsip, Penerapan, dan Penelitian. Yogyakarta.

Tjiptono, F. G. C. (2011). Service, Quality and Satisfaction Edisi 3. Yogyakarta: Andi. 